\title{
A GAME-BASED MODEL TO ENHANCE LEARNING AT UNIVERSITY
}

\author{
Martina Marsano \\ Department of Education, University of Roma Tre (Italy)
}

\begin{abstract}
The present doctoral research, through the adoption of a game-based model, intends to promote the development of learning strategies of the students who encounter greater difficulties along their academic path. The game-based model consists in educational activities that have characteristics linked to the dimensions of video games, gamification and Alternate Reality Games. Particularly, the game-based model targets students of the Degree Courses in Educational Sciences and Primary Teacher Education of the University of Roma Tre that have encountered greater difficulties in their studies. The paper presents the results obtained at the end of the try-out phase, which was carried out within two workshops of the Degree Course of Primary Teacher Education at the University of Roma Tre with the aim of testing some components of the game-based model.
\end{abstract}

Keywords: Learning strategies, university, gamification, learning.

\section{Introduction}

Recent data and research (Burgalassi et al., 2016; Eurostat, 2017; Anvur, 2016) have highlighted the problem related to the high university dropout rate in Italy. Indeed, Italy is among the countries with the highest dropout rate in Europe and at the same time one of the latest countries for the number of people holding a tertiary education degree (26,5\% against $40 \%$ of the other European countries). Moreover, the university courses are often attended by a very low number of students (on average less than half of the enrolled students), which consequently have few opportunities of establishing meaningful relationships with their fellow students and/or professors and to acquire the necessary skills to understand how to face the university context.

\section{Theoretical background}

Several authors (Huizinga, 1946; Caillois, 1981; Fink, 2008) have emphasized the importance of play, which is linked to cultural aspects, but also strongly connected to learning (Froebel, 1967; Vygotsky, 1972; Garvey 1979). In recent decades, the scientific literature has also highlighted the educational potential of video games that, thanks to their characteristics, allow the subject to learn in an interactive and highly immersive environment, promoting an experiential learning (Gee, 2003; Salen, 2008; Squire, 2011; De Castro, 2016). At the same time, also gamification, which refers to the use of game elements in non-game contexts (Deterding et al., 2011), has been used in education, for example, in the university context to promote students' motivation, interest and participation (Sanchez-Carmona et al., 2017; Bajko, et al. 2016; Leaning, 2015; O’Donovan et al., 2013). There are also experiences on the use of Alternate Reality Games (ARG) in education (Connolly et al., 201; Bonsignore et al., 2013; Gilliam et al., 2016). ARG are interactive experiences that focus on the narration of a story that develops both within real life contexts and digital ones (Szulborski, 2005; Palmer \& Petroski, 2016).

\section{Objectives and methods}

The present research, which is still ongoing, represents a pilot study that uses quali-quantitative tools and that involves some students enrolled in the second year of the Degree Courses in Education Sciences and in Primary Teacher Education at the Department of Education at University of Roma Tre. The assumption at the base of the study concerns the fact that the introduction in educational contexts of elements derived from the dimensions of video games, gamification and Alternate Reality Games seems to have a positive impact on learning (Griffiths, 2002; Hamari et al., 2015; Steinkuehler \& Squire, 2015; Ebrahimzadeh \& Alavi, 2017; Liu, 2017; Kaufmann, 2018; Chapman \& Rich, 2018; Hitchens, \& Rowan, 2018). 
Therefore, the goal of the present research is to verify the effectiveness that elements derived from games and video games can bring within the support strategies (for example in the tutoring services) to university students who have encountered difficulties in their academic path. The research question is the following: to what extent can the introduction of elements derived from the dimensions of video games, gamification and Alternate Reality Games within a set of activities related to the six areas of competence of the Questionnaire for Learning Strategies (Pellerey \& Orio, 1996) encourage the promotion of learning strategies in university students who are critical in their studies? It is assumed that, through the adoption of the game-based model, students who present issues in their study can obtain benefits on the implementation of their self-regulating skills both on the qualitative level (orientation, motivation to learn, interest, attitude, social relationships) and on the quantitative one (frequency of lessons, improvements of the grades). The presence of any changes in the profile of the students will be detected through qualitative procedures (self reports, interviews, focus groups) and by referring to academic performance (grades and number of exams taken).

In order to select the sample involved in the pilot study, three questionnaires were used to identify the critical elements encountered in the study experience by the students of the Degree Courses in Education Sciences and Primary Teacher Education: the Questionnaire for Learning Strategies (QSA-Pellerey \& Orio, 1996), the Zimbardo Time Perspective Inventory (ZTPI-Zimbardo \& Boyd, 1999; Tr. It Riccucci, 2009) and the Questionnaire on the University Study Experience (QuESU) ${ }^{1}$. In order to select the students, we referred to the critical issues that emerged in their profiles of the QSA and the ZTPI, also on the basis of the characteristics that presents the profile of the disoriented student (La Rocca, Margottini \& Capobianco, 2014), who shows difficulty in controlling his/her emotional states, high levels of disorientation, difficulty concentrating on the studies, lack of perseverance, attribution of his/hers successes or failures to uncontrollable causes.

Although there are several models related to the use of gamification in education (Uhr et al., 2015; Rutkauskiene et al., 2016; Zaric et al., 2017), the game-based model presented in this contribution is based on the six areas of competence related to the Questionnaire for Learning Strategies. The six areas of competence are: managing processes and strategies for understanding and remembering; orientating and organizing in the study tasks; relating and collaborating with others; controlling and managing anxiety and emotions; perceiving competence and locus of control; controlling and protecting emotions. Specifically, the Questionnaire for Learning Strategies, a tool validated and used both in schools and in universities (Pellerey, 1996; Pellerey et al., 2013; Margottini \& Rossi, 2017; La Rocca, Margottini \& Capobianco, 2014), consists in 100 items, that refer to fourteen evaluation scales (seven of them are linked to the cognitive sphere and seven to the affective-motivational sphere). Each of the fourteen evaluation scales pertains to a specific area of competence. Through the proposal of a game-based model of didactic support we intend to reformulate the activities that allow to enhance each area of competence - some of these activities are taken from Ottone's volume (2014) - through the introduction of features derived from the dimensions of video games, gamification and Alternate Reality Game. Therefore, for each area of competence we foresee activities aimed at strengthening learning strategies that fall within that specific area, such as: the creation of concept maps on the topics of the course, group work to deepen the topics of the course and activities that aim to promote the reflection on the link between emotions and learning.

\section{The try-out phase}

Within the present research, a try-out phase has been carried out along two workshops with the students of the Degree Course in Primary Teacher Education of the University of Roma Tre.

The first try-out was carried out within the Workshop of Educational Technologies (coordinator of the workshop is Professor Daniela Olmetti Peja) in the months of March and April 2018. The objective of the workshop, developed over five meetings, was to provide fourth-year students with the ability to understand the characteristics of serious game, video games specifically designed for learning (Abt, 1970), and also making them reflect on the possible use of these games in their professional future. In this sense, students, working in small groups, had to create the storyboard of a serious game to be used in school contexts. After a brief theoretical lesson about the characteristics of mainstream video games and on the ways by which they engage the players, students were given the opportunity to play with a serious game on their smartphones: Father and Son, a game produced by the National Archaeological Museum of Naples. The game offers the opportunity to explore some areas of the museum and also to travel back in time, for example, in ancient Egypt. After their gaming experience, students were able to reflect on the differences observed between mainstream video games and serious games. In light of the feedback received, a brief theoretical introduction on the characteristics of serious games has been proposed and on how these tools

\footnotetext{
${ }^{1}$ The QuESU questionnarie has been created specifically for the present research.
} 
are used to fostering learning in the didactic field. Then, students worked on the creation of the game, deciding: the topic and the subject connected to it; the target; the goal, namely what it was possible to learn by playing with it; the plot; the characters; the mechanics of the game. The storyboard technique allowed students to realize a graphic representation of the main sequences of the game; students also included short captions in order to describe the different scenes. The feedback from the participants was positive and the serious games realized focused on topics such as geography, civics, English, etc.

The second try-out was instead carried out in May 2018 within the Workshop of Special Pedagogy and Didactics 2, (coordinator of the workshop is Professor Fabio Bocci, who is also the supervisor of this $\mathrm{PhD}$ research), involving students enrolled in the third year. The goal of this workshop - which was developed over four days - was to making students reflect on the issues encountered more regularly during their academic path and stimulating them by solving these issues with proposal connected to the use of game mechanics. First of all, students were invited to carry out individual and group self-analysis work on the difficulties and problems encountered more regularly in their university experience. The participants also had to make short interviews with friends or fellow students to understand the difficulties encountered by them. During the second day, the participants met the students working within the Department's tutoring services in order to obtain further information on the most widespread difficulties and to understand the ways in which these services respond. Then, divide in small groups, they realized a map of the difficulties encountered by them at university. The most common problems identified by the students concerned the lack of spaces for studying, the difficulty in communicating with academic staff, the difficulty of working students in balancing university life with work, the difficulty in finding the needed information for carrying out certain educational activities. During the third meeting, students were then given a short presentation on the use of video games, gamification and Alternate Reality Games in the educational field and, subsequently, the groups were invited to make proposals for the resolution of the difficulties encountered: the proposals had to have ludic characteristics. Students, in carrying out the group work, elaborated proposals based in particular on the use of technologies. Indeed, students' proposals were based on the creation of Apps or digital platforms, characterized by the presence elements derived from videogames and in which they could interact in a simple, fast and effective way both with their fellow students, with the tutors of the services and with the academic staff (teachers and administration). The students' preference for the use of Apps and digital platforms to communicate is probably due to the fact that they have grown up within an environment strongly characterized by the presence of technologies, which inevitably have influenced their way of interacting with others.

\section{Discussion}

The two workshops activities presented are part of the try-out phase of the present pilot study. Through the first try-out, it was possible to understand the level of knowledge of students towards serious games and this workshop has represented for many of them a first approach with topics concerning the use of video games in the educational field. In particular, serious games can be useful educationl tools for their future role as teachers. Through the second workshop, it was possible to reflect on the introduction in the university field of some typical mechanics of video games, gamification and Alternate Reality Game in order to improve the orientation and the communication between students and academic staff.

This phase represented a preliminary and introductory stage of the pilot study, which will involve the use of some components of these approaches within the activities that will be part of the game-based model.

\section{Conclusion}

The present research, which represents a pilot study, starting from the identification of the critical issues encountered in the study by the university students along their academic path, intends to promote the development of their learning strategies through a series of educational activities characterized by the presence of elements derived from games and video games.

The opportunity to learn in an environment that also has characteristics derived from games and video games, can represent a modality through which promotoing an academic study experience that can be perceived positively by the students - which belong to the Millennials generation and are also defined as digital natives (Prensky, 2001).

The activities of the game-based model refer to a validated tool, namely the Questionnaire for Learning Strategies (QSA-Pellerey \& Orio, 1996) - indeed all the activities of the model are based on the six areas of competence of the QSA. This makes us believe that it is possible to enhance the learning strategies of the students, also making use of the presence, within the activities, of elements taken from games and video games. 


\section{References}

Abt, C. (1970). Serious games. New York: Viking Press.

Anvur (2016). Rapporto biennale sullo stato del sistema universitario e della ricerca 2016. Roma: Anvur.

Bajko, R., Hodson, J., Seaborn, K., Livingstone, P., \& Fels, D. (2016). Edugamifying Media Studies: Student Engagement, Enjoyment, and Interest in Two Multimedia and Social Media Undergraduate Classrooms. Information System Education Journal, 14(6), 55-72.

Bonsignore, E., Derek, H., Kraus, K., \& Ruppel, M. (2013). Alternate reality games as platforms for practicing 21st-century literacies. International Journal of Learning and Media, 4(1), 25-54.

Burgalassi, M, Biasci, V., Capobianco, R., \& Moretti, G. (2016). Il fenomeno dell'abbandono universitario precoce. Uno studio di caso sui corsi di laurea del Dipartimento di Scienze della Formazione dell'Università "Roma Tre". Giornale Italiano della Ricerca Educativa, 9(17), 105- 126.

Caillois, R. (1981). I giochi e gli uomini: la maschera e la vertigine. Milano: Bompiani.

Chapman, J. R., \& Rich, P. (2018). Does Educational Gamification Improve Students' Motivation? If so, Which Game Elements Work Best? Journal of Education for Business, 93(7), 314-321.

Chu, Y. (2015). Actionable Gamification: Beyond Points, Badges, and Leaderboards. Octalysis Media.

Connolly, T., Stansfied, M., \& Hainey, T. (2011). An alternate reality game for language learning: ARGuing for multilingual motivation. Computers \& Education, 57(1), 1389-1415.

De Castro, M. (2016). Apprendimento esperienziale, game studies e didattica per immersione. In F. Bocci, B. De Angelis, C. Fregola, D. Olmetti Peja, U. Zona, Rizodidattica. Teorie dell'apprendimento e modelli didattici inclusivi (pp. 287-327). Lecce: Pensa Multimedia.

Deterding, S., Dixon, D., Khaled, R., \& Nacke, L. (2011). From game design elements to gamefulness: defining "gamification". Proceedings of the 15th International Academic MindTrek Conference: Envisioning Future Media Environments, 9-15.

Ebrahimzadeh, M., \& Alavi, S. (2017). The Effect of Digital Video Games on EFL Students' Language Learning Motivation. Teaching English with Technology, 17(2), 87-112.

Eurostat. (2017a). Education and training statistics at regional level. Retrived from http://ec.europa.eu/eurostat/statisticsexplained/index.php?title=Education_and_training_statistics_at_regional_level.

Fink, E. (2008). Oasi del gioco. Milano: Raffaello Cortina.

Froebel, F. (1967). L'educazione dell'uomo e altri scritti. Firenze: Nuova Italia.

Garvey, C. (1979). Il gioco: l'attività ludica come apprendimento. Roma: Armando Editore.

Gee, J.P. (2003). What video games have to teach us about learning and literacy. New York: Palgrave Macmillan.

Gilliam, M., Bouris, A, Hill, B., \& Jagoda, P. (2016). "The Source": An Alternate Reality Game to Spark STEM Interest and Learning among Underrepresented Youth. Journal of STEM Education: Innovations and Research, 17(2), 14-20.

Griffiths, M. (2002). The educational benefits of videogames. Education and Health, 20(3), 47-51.

Hamari J., Shernoff, D., Rowe, E., Coller, B., Asbell-Clarke, J., \& Edwards, T. (2015). Challenging games help students learn: an empirical study on engagement, flow and immersion in game-based learning. Computers in Human Behavior, 54(2016), 170-179.

Hitchens, M., \& Tulloch, R. (2018). A Gamification Design for the Classroom. Interactive Technology and Smart Education, 15(1), 28-45.

Huizinga, J. (1946). Homo ludens. Torino: Einaudi.

Kaufmann, D. (2018). Reflection: Benefits of Gamification in Online Higher Education. Journal of Instructional Research, 7, 125-132.

Kim, J.T. \& Lee, W.H. (2013). Dynamical model and simulations for gamification of learning. International Journal of Multimedia and Ubiquitous Engineering, 8(4), 179-189.

La Rocca, C., Margottini, M., \& Capobianco, R. (2014). Ambienti digitali per lo sviluppo delle competenze trasversali nella didattica universitaria. ECPS-Educational, Cultural and Psychological Studies, 10, 245-283.

Leaning, M. (2015). A study of the use of games and gamification to enhance student engagement, experience and achievement on a theory-based course of an undergraduate media degree. Journal of Media Practice, 16(2), 155-170.

Liu, C. L. (2017). Using a Video Game to Teach Supply Chain and Logistics Management. Interactive Learning Environments, 25(8), 1009-1024.

Margottini, M., \& Rossi, F. (2017). Il ruolo delle dinamiche cognitive, motivazionali e temporali nei processi di apprendimento. Formazione \& Insegnamento-European Journal of Research on Education and Teaching, 15(2), 499-511. 
O’Donovan, S., Gain, J., \& Marais, P. (2013). A case study in the gamification of a university-level games development course. SAICSIT'13-Proceedings of the South African Institute for Computer Scientists and Information Technologists Conference, 242-251.

Oliveira, S. \& Cruz, M. (2018). The Gamification Octalysis Framework within the Primary English Teaching Process: the Quest for a Transformative Classroom. Revista Lusófona de Educação, 41, 63-82.

Ottone, E. (2014). Apprendo: strumenti e attività per promuovere l'apprendimento. Roma: Anicia.

Palmer, C. \& Petroski, A. (2016). Alternate Reality Games: Gamification for Performance. Boca Raton: CRC Press.

Pellerey M., Grzadziel D., Margottini M., Epifani F., \& Ottone E. (2013). Imparare a dirigere se stessi. Progettazione e realizzazione di una guida e di uno strumento informatico per favorire l'autovalutazione e lo sviluppo delle proprie competenze strategiche nello studio e nel lavoro. Roma: CNOS-FAP.

Pellerey, M., \& Orio, F. (1996). Questionario sulle strategie di apprendimento (QSA). Con 25 schede e floppy disk. Roma: Las.

Prensky, M. (2001). Digital Natives, Digital Immigrants Part 1. On the Horizon, 9(5), 1-6.

Rutkauskiene, D., Gudoniene, D., Maskeliunas, R., \& Blazauskas, T. (2016). The Gamification Model for E-Learning Participants Engagement. In Uskov V., Howlett R., Jain L. (Eds), Smart Education and e-Learning 2016. Smart Innovation, Systems and Technologies (pp. 291-301). Cham: Springer.

Salen. K. (2008). The ecology of games: connecting youth, games, and learning. Cambridge, Mass.: The MIT Press.

Sanchez-Carmona, A., Robles, S., \& Pons, J. (2017). A gamification experience to improve engineering students' performance through motivation. Journal of Technology and Science Education, 7(2), $150-161$.

Squire, K. (2011). Video Games and Learning: Teaching and Participatory Culture in the Digital Age. New York: Teachers College Press.

Steinkuehler, C., \& Squire, K. (2015). Videogames and Learning. In K.R. Sawyer (Ed.), The Cambridge Handbook of the Learning Sciences (pp. 377-394). New York: Cambridge University Press.

Szulborski, D. (2005). This is not a game: a guide to Alternate Reality Gaming. Macungie, PA: New-Fiction Publishing.

Uhr, M., Vukovic, G., Jereb, E. \& Pintar, R. (2015). The Model for Introduction of Gamification into E-learning in Higher Education. Procedia - Social and Behavioral Sciences, 197, 388-397.

Zaric N., Scepanović S., Vujicic T., Ljucovic J., \& Davcev D. (2017). The Model for Gamification of E-learning in Higher Education Based on Learning Styles. In Trajanov D., Bakeva V. (Eds.) ICT Innovations 2017. Data-Driven Innovation (pp. 265-273). Cham: Springer.

Zimbardo, P. G., \& Boyd J. N. (2009). Il paradosso del tempo. La nuova psicologia del tempo che cambierà la tua vita. Milano: Oscar Mondadori.

Zimbardo, P. G., \& Boyd, J. N. (1999). Putting time in perspective: A valid, reliable individual difference metric. Journal of Personality and Social Psychology, 77(6), 1271-1288. 